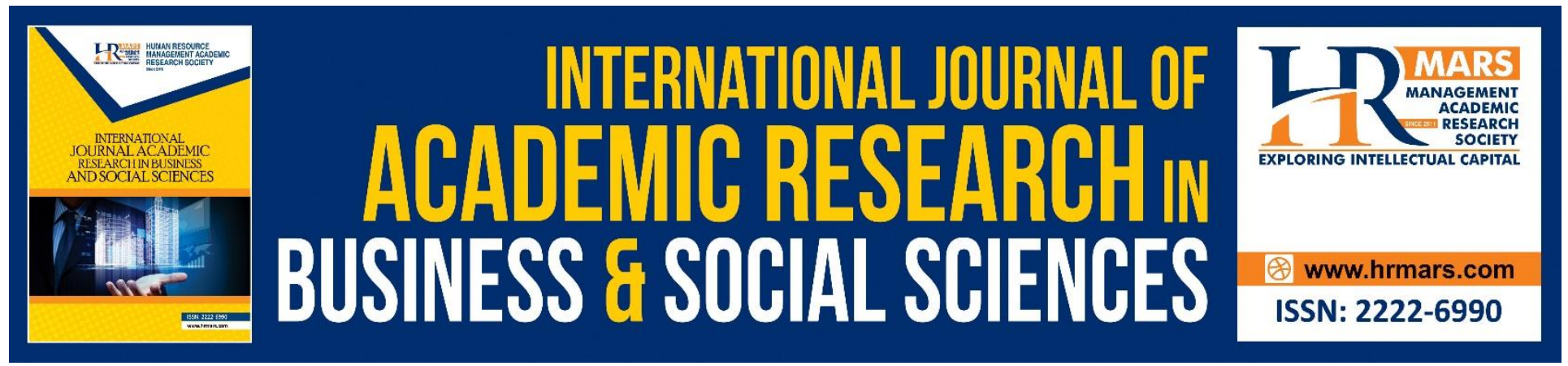

\title{
Students Perceptions towards Public Relations Course and the Implication towards their Academic Performance
}

Abdul Rauf bin Ridzuan, Siti Nirmala Binti Mohamad Ishak, Rosilawati Sultan Mohideen, llya Yasnorizar Ilyas, Wan Hartini Wan Zainodin, Mohd Khairornizam Mohd Yunus

To Link this Article: http://dx.doi.org/10.6007/IJARBSS/v8-i10/4786 DOI: $10.6007 /$ IJARBSS/v8-i10/4786

Received: 27 Sept 2018, Revised: 17 Oct 2018, Accepted: 25 Oct 2018

Published Online: 09 Nov 2018

In-Text Citation: (Ridzuan et al., 2018)

To Cite this Article: Ridzuan, A. R. bin, Ishak, S. N. B. M., Mohideen, R. S., Ilyas, I. Y., Zainodin, W. H. W., \& Yunus, M. K. M. (2018). Students Perceptions towards Public Relations Course and the Implication towards their Academic Performance. International Journal of Academic Research in Business and Social Sciences, 8(10), 883-889.

Copyright: (C) 2018 The Author(s)

Published by Human Resource Management Academic Research Society (www.hrmars.com)

This article is published under the Creative Commons Attribution (CC BY 4.0) license. Anyone may reproduce, distribute, translate and create derivative works of this article (for both commercial and non-commercial purposes), subject to full attribution to the original publication and authors. The full terms of this license may be seen

at: $\underline{\text { http://creativecommons.org/licences/by/4.0/legalcode }}$

Vol. 8, No. 10, 2018, Pg. 883 - 889

http://hrmars.com/index.php/pages/detail/IJARBSS

JOURNAL HOMEPAGE

Full Terms \& Conditions of access and use can be found at http://hrmars.com/index.php/pages/detail/publication-ethics 


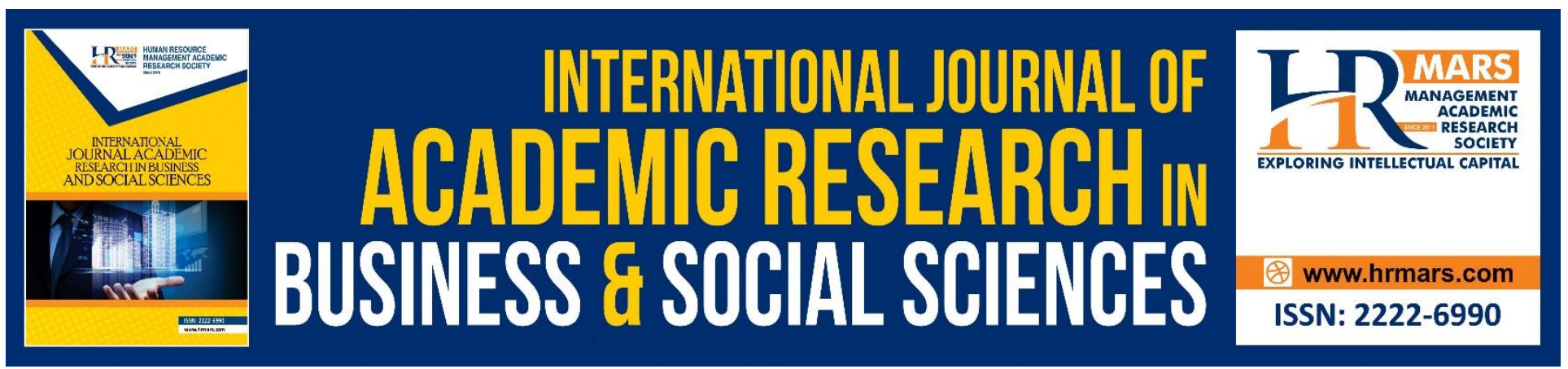

\title{
Students Perceptions towards Public Relations Course and the Implication towards their Academic Performance
}

\author{
Abdul Rauf bin Ridzuan, Siti Nirmala Binti Mohamad Ishak, \\ Rosilawati Sultan Mohideen, Ilya Yasnorizar llyas, Wan Hartini Wan \\ Zainodin, Mohd Khairornizam Mohd Yunus \\ Faculty of Communication \& Media Studies, Universiti Teknologi Mara Melaka
}

\begin{abstract}
The ultimate aim of Public Relations is to present organizations in the best light possible. This requires special skills in the area of research, managerial, persuasive communication, strategic planning and writing. The standpoint is needed to evaluate the progressive of the profession growth in the industry. Public Relations itself can be a best platform for a person to represent themselves and express their interest towards the profession. This research examined the perceptions towards Public Relations course and their academic performance. The amount of survey calculated based on Krejcie and Morgan Table, $\mathrm{N}=95, \mathrm{~S}=76$ by using purposive sampling method. Descriptive quantitative research study was conducted through survey using questionnaire form. The hypothesis testing gained by using two different methods which indicated different result which are Pearson Correlation and Multiple Linear Regression. Based on the research by using Pearson Correlation method, the five listed null hypothesis is accepted based on the standardized significant values which is must be or less than 0.05. However, based on Multiple Linear Regression method, there is different reading which formed different results. Based on significant value in Coefficient Multiple Linear Regression analysis, the null hypothesis of self-interest (0.042) and industry prospect $(0.037)$ is being accepted with significant value below than 0.05 .
\end{abstract}

Keynote: Public Relations, Motivation Factor, Perception, Influence Factor

INTRODUCTION

An extensive decision making to choose the suitable college major which represents a major life decision may become the most difficult process. Some of undergraduate or post-secondary student admit that they can make their own decision making without referring to the guideline. Some of them might choose their college major course based on their interest, influence by their surrounding such as family and friends or some of them being more influence towards the course job scope and 
opportunity. Most of graduating student especially from the secondary school may not have a solid decision on deciding where the suitable college or what the most suitable degree course to further their study (Ramirez \& Dizon, 2014). Academic institution is responsible to promote and preparing the guideline for an educational program to promote the possible course or college (Nadelson, 2013). Some of the student may not have enough knowledge or awareness about the application process or how they should choose the course based on their ability and academic performance. Pafili and Mylonakis (2011) believe that the right decision towards the proper profession and courses can successfully utilize their skill and knowledge that could contribute to the development of society and country. However, some of studies shown that not all the students who further their study to the university have the intention to obtain the qualification.

The research study is only focused for Bachelor of Public Relations students in UiTM Alor Gajah, Melaka. As the first batch to be the main pioneer in the campus with 21 students for the first intake on September 2015, it is a big improvement and a new platform for new courses establishment in Faculty of Communication and Media Studies. The courses students' intake now almost reached to 95 students to further their study in Bachelor of Public Relations.

This research will give us the overview of tendency by the student in choosing these courses and perception towards the courses content itself. The factors of the tendency may include the motivation factors, family and education background, and self-interest and how the student states their own perception towards the courses. Furthermore, the research can be used by the educator to study the enhancement and rational of the courses established in the campus. Tendency factors and students perception can be shown by how their academic performance and their involvement towards the course assessment itself. The findings and data analysis are important for the education institute to play their roles in enhancing the study environment or the on-going assessment itself for an excellent academic performance.

\section{PROBLEM STATEMENT}

Academic performance of students has been of great concern to educationists, guidance and counselors. It is important for the student to choose suitable course based on their interest, ability and previous academic performances. Decision making process can be influence by various factors that indicated towards the future results and performances. Education institution plays an important role to give an exposure to the student about the background and potential course to wisely choose the suitable field.

Such of influence factors and perceptions discussed in the study indicated that there are significantly affected the decision making process. Motivation from internal and external factors, family and education background, self-interest are the main influence factors that indicated the tendency of the student to choose the suitable course and academic performances.. Industry prospect and course assessment content are two main dimensions of perceptions that indicated the result towards the student performances. 
Main issues for secondary school student are about to make right choice and decision making. Some of them might not have a clear exposure or academic guideline towards the provided and suitable course based on their ability and academic performances. If they failed to make correct decision making on the selected course, they may tend to have a problem during the university academic session or it might cause to risk their job opportunity.

\section{THE PERCEPTION TOWARDS PUBLIC RELATIONS COURSE}

\section{- Content and Course Assessment}

The students performances during class can be observe and measure by the development of direct involvement of the student from classroom instruction, group work and activities. It can be considered as a valid and reliable method to facilitate the student's participation in evaluation process. The evaluation process can be control and observe through the given task, decision making, problem solving and the implementation of the skill through the student presentations.

\section{- Industry Prospect}

A recent study by Richardson's (2009), the perceptions of Australian tourism and hospitality students was important factors for them to choice of career and the extent to which a career in these industries would offer those factors as an enjoyable job, pleasant working environment, job security, colleagues they can get along with and high earnings over the length of their career were the most important.

\section{ACADEMIC PERFORMANCES}

Education plays an essential role in the acquisition of knowledge and skills. It is a tool which can be used to train the future generations to inculcate skills and competencies. The way a child is raised has an adverse impact not only to oneself but to the whole society. While growing up the child spends most of his time at home and the type of environment he or she is brought in also hamper their cognitive development. In order to help a child grow in good health, parents should come into the picture in shaping the child's character and frame of mind. Literature around the globe shares that the level of education which the parents have achieved can also affect the child's growth as literate parents have the ability to instill wisdom acquired by them to their children. Literate and illiterate parents differ in the sense of being able to read and write and the accumulation of skills and knowledge of certain fields of study.

\section{RESEARCH METHODOLOGY}

This research examined the study of factors and perceptions towards the student's school and academic performances and their tendency to choose Public Relations course as the main options. The amount of survey calculated based on Krejcie and Morgan Table, N=95 , S=76 by using purposive sampling method. Descriptive quantitative research study was conducted through survey using questionnaire form. The hypothesis testing gained by using two different methods which indicated different result which are Pearson Correlation and Multiple Linear Regression (Abdul Rauf Ridzuan et al., 2015). 
INTERNATIONAL JOURNAL OF ACADEMIC RESEARCH IN BUSINESS AND SOCIAL SCIENCES

Vol. 8, No. 10, Oct. 2018, E-ISSN: 2222-6990 @ 2018 HRMARS

\section{RESULTS AND DISCUSSIONS}

a) Profile of the Public Relations Bachelor Student of UiTM Melaka

The profile of the sample is discussed in terms of six characteristics: sex, age group, current semester, previous education, PR as first choice and the happiness towards the choices.

Table 1: Distribution of Public Relations Bachelor Student by Profile ( $n=95)$

\begin{tabular}{|c|c|c|}
\hline ITEM & FREQUENCY & PERCENTAGE \% \\
\hline \multicolumn{3}{|l|}{ SEX } \\
\hline - MALE & 22 & 23.2 \\
\hline - FEMALE & 73 & 76.8 \\
\hline \multicolumn{3}{|l|}{ AGE GROUP } \\
\hline - $19 \mathrm{Y} / \mathrm{O}$ & 6 & 6.3 \\
\hline - $20 \mathrm{Y} / \mathrm{O}$ & 27 & 28.4 \\
\hline - $21 \mathrm{Y} / \mathrm{O}$ & 30 & 31.6 \\
\hline - $22 \mathrm{Y} / \mathrm{O} \& \mathrm{ABOVE}$ & 32 & 33.7 \\
\hline \multicolumn{3}{|l|}{ CURRENT SEMESTER } \\
\hline - 1 & 22 & 23.2 \\
\hline - 2 & 20 & 21.1 \\
\hline - 3 & 15 & 15.8 \\
\hline - 4 & 16 & 16.8 \\
\hline - 5 & 22 & 23.2 \\
\hline \multicolumn{3}{|l|}{ PREVIOUS EDUCATION } \\
\hline - STPM & 46 & 48.4 \\
\hline - MATRICULATION & 18 & 18.9 \\
\hline - FOUNDATION & 15 & 15.8 \\
\hline - DIPLOMA & 16 & 16.8 \\
\hline \multicolumn{3}{|l|}{ PR AS FIRST CHOICE } \\
\hline - YES & 57 & 60 \\
\hline - NO & 38 & 40 \\
\hline \multicolumn{3}{|l|}{ HAPPINESS WITH THE CHOICE } \\
\hline - YES & 81 & 85.3 \\
\hline - NO & 14 & 14.7 \\
\hline
\end{tabular}

Table 1 above shows the profile of respondents of Public Relations degree student in UiTM Alor Gajah, Melaka is from different background. Based on the female is the dominant population in the sample of study which is involving $76.8 \%$. The highest age group of the student is 22 years old and above which represent $33.7 \%$. The highest previous education background is mostly come from STPM 
INTERNATIONAL JOURNAL OF ACADEMIC RESEARCH IN BUSINESS AND SOCIAL SCIENCES Vol. 8, No. 10, Oct. 2018, E-ISSN: 2222-6990 @ 2018 HRMARS

qualification which indicated 48.4\%. From 95 Bachelor in Public Relations students, only $60 \%$ is possible to choose Public Relations course as the first choice. However, most of the population which represents $85.3 \%$ is happy with their decision to choose Public Relations course.

Table 1 : Coefficient for Multiple Regression Analysis Coefficients ${ }^{a}$

\begin{tabular}{|c|c|c|c|c|c|}
\hline & \multicolumn{2}{|c|}{$\begin{array}{l}\text { Unstandardized } \\
\text { Coefficients }\end{array}$} & \multirow{2}{*}{$\begin{array}{c}\text { Standardized } \\
\text { Coefficients } \\
\text { Beta }\end{array}$} & \multirow[t]{2}{*}{$t$} & \multirow[t]{2}{*}{ Sig. } \\
\hline & B & Std. Error & & & \\
\hline (Constant) & .735 & .46 & & 1.600 & .113 \\
\hline Course \& Assessment Content & .185 & .12 & .171 & 1.542 & .127 \\
\hline Industry Prospect & .252 & .12 & .234 & 2.116 & .037 \\
\hline
\end{tabular}

a. Dependent Variable: STUDENT PERFORMANCE

The Coefficient table above shows Beta value for all the independent variables when they are regressed jointly against dependent variable. Based on the standardized coefficients reading, the Beta values for all independent show positive relationship towards the dependent variables.

- $H_{1}$ The higher the level perception towards the course content and assessment, the higher the level of student's performances.

The Perception 1 which refer to the perception towards the content and course assessment with positive Beta value $(\beta=0.171)$ at significant value $(p=0.127)$. The null hypothesis is rejected and accepts the new alternate hypothesis. The enhancement of individual skill based on their learning process will directly influence their interest towards the course and positively affect on the academic performances (Linn \& Miller, 2005).

- $\mathrm{H}_{2}$ The higher the level perception towards the industry prospect, the higher the level of student's performances.

Perception 2 which refers to the industry prospect indicated the highest Beta value which is $(\beta=0.234)$ at significant level $(p=0.037)$. Thus, the null hypothesis is accepted because the significant level is $(p<0.05)$. Coulthard $(2000)$ said that the perception and influence from the industry will encourage an individual to positively attract towards the school performance and social interaction.

\section{CONCLUSION}

Based on Multiple Linear Regression method, there were two indicated result based on the coefficients analysis. The first reading indicated the Beta $(\beta)$ values which represent the significant relations directly from the independent towards dependent variables. The Beta $(\beta)$ values shown, industry prospect $(\beta=0.234)$ was the strongest significant relations towards the dependent variable of student's academic performance which influenced the tendency of the decision-making process 
INTERNATIONAL JOURNAL OF ACADEMIC RESEARCH IN BUSINESS AND SOCIAL SCIENCES Vol. 8, No. 10, Oct. 2018, E-ISSN: 2222-6990 ㄷ 2018 HRMARS

to choose Public Relations course. Besides, based on coefficients significant level of Multiple Linear Regression analysis indicated the standardized significant value must be or less than 0.05 . From this findings, most of students have chosen public relations course because of good industry prospect that they think has bright future which will make them perform very well in their education.

\section{Acknowledgement}

Researchers would like to say thank you to Deputy Rector of Research in UiTM Cawangan Melaka, Associate Prof Dr Shafinar Ismail and Melina Mahpuz, Deputy Dean of Research and Industry Linkage from Faculty of Communication \& Media Studies, UiTM Shah Alam for their encouragement and motivation to do this research.

\section{Corresponding Author}

Abdul Rauf Ridzuan (PhD), Faculty of Communiation \& Media Studies, UiTM Cawangan Melaka, Malaysia.

Email abdulrauf@melaka.uitm.edu.my

\section{References}

Ainley, M., Hidi, S., \& Berndorff, D. (2002). Interest, learning, and the psychological processes that mediate their relationship. Journal of educational psychology, 94(3), 545.

Bandura, A. (1997). The nature and structure of self-efficacy. Self-efficacy: the exercise ofcontrol. New York, NY: WH Freeman and Company, 37-78.

Cronbach, L. J. (1951). Coefficient alpha and the internal structure oftests. psychometrika, 16(3), 297-334.

Epstein, J. L. (1995). School/family/community partnerships. Phi delta kappan, 76(9), 701.

Giroux, H. A. (1988). Teachers as intellectuals: Toward a critical pedagogy of learning.

Grunig, J. E., \& Hunt, T. T. (1984). Managing public relations. Holt, Rinehart and Winston.

idi, S. (1990). Interest and its contribution as a mental resource for learning. Review ofEducational research, 60(4), 549-571.

Kimani, G. N., Kara, A. M., \& Njagi, L. W. (2013). Teacher factors influencing students'academic achievement in secondary schools in Nyandarua County, Kenya. International journal of education and research, 1(3), 1-14.

Nadelson, L. S., Callahan, J., Pyke, P., Hay, A., Dance, M., \& Pfiester, J. (2013). TeacherSTEM perception and preparation: Inquiry-based STEM professional development for elementary teachers. The Journal of Educational Research, 106(2), 157-168. 